\title{
Pemanfaatan Perpustakaan Digital Sebagai Sumber Belajar Elektronik Pada Masa Pandemi COVID-19 Di Tingkat SMA
}

\section{The Utilisation of Digital Libraries as Electronic Learning Resources During the COVID-19 Pandemic at SMA Negeri 3 Batam}

\author{
Angga Hadiapurwa, Rayhan Musa Novian, \& Noviandi Harahap \\ Universitas Pendidikan Indonesia, Bandung, Jawa Barat, Indonesia \\ angga@upi.edu
}

Naskah diterima tanggal 15/04/2021, direvisi akhir tanggal 12/07/2021, disetujui tanggal 01/08/2021

\begin{abstract}
Abstrak
Pemerintah Indonesia melalui Kementerian Pendidikan telah memberikan himbauan kepada seluruh sekolah untuk melaksanakan pembelajaran secara daring sebagaimana yang tercantum dalam Surat Edaran Menteri Pendidikan dan Kebudayaan Republik Indonesia Nomor 4 Tahun 2020 tentang Pelaksanaan Pendidikan dalam Masa Darurat Coronavirus Disease (COVID-19). Akibatnya, banyak siswa yang kesulitan untuk menjalani proses pembelajaran secara daring karena terbatasnya sumber belajar elektronik. Berangkat dari masalah tersebut, perlu hadirnya perpustakaan digital yang dapat dijadikan sebagai salah satu sumber belajar bagi siswa untuk mengoptimalkan proses pembelajaran daring. Penelitian ini dialaksanakan dengan menggunakan metode design and development dalam pengembangan perpustakaan digital. Untuk studi awal mengunakan kuisioner untuk menjawab permasalahan dalam pengembangan perpustakaan digital yang melibatkan siswa-siswi SMA Negeri 3 Batam sebagai subjek penelitian. Berdasarkan data yang diperoleh, diketahui bahwa sebanyak $31.80 \%$ siswa kesulitan untuk mendapatkan sumber belajar selama proses pembelajaran daring. Oleh sebab itu, menghadirkan perpustakaan digital merupakan langkah yang tepat untuk mengoptimalkan pembelajaran daring selama masa pandemi COVID-19.
\end{abstract}

Kata Kunci: COVID-19, Daring, Perpustakaan Digital, Pembelajaran dan Sumber Belajar.

\begin{abstract}
The Indonesian government, through the Ministry of Education and Culture, has appealed to all schools to carry out online learning as stated in the Circular of the Minister of Education and Culture of the Republic of Indonesia Number 4 of 2020 concerning the Implementation of Education in the Emergency Coronavirus Disease (COVID-19). As a result, many students find it difficult to undergo the learning process online due to limited electronic learning resources. Departing from this problem, it is necessary to have a digital library that can be used as a learning resource to optimize the online learning process. This research was carried out using descriptive quantitative methods involving SMA Negeri 3 Batam students as research subjects. Based on the data obtained, it is known that as many as $31.80 \%$ of students find it difficult to get learning resources during the online learning process. Therefore, presenting a digital library is the right step to optimize online learning during the COVID-19 pandemic
\end{abstract}

Keywords: COVID-19, Online learning, Digital Library, Learning and Educational resources 


\section{PENDAHULUAN}

Coronavirus yang dikenal sebagai "COVID-19" telah menyebar dengan cepat ke lebih dari 60 negara di seluruh dunia (Rusiadi, R. et al., 2020). Beberapa penulis telah membahas asal mula virus. Sebagai contoh, Andersen et al., (2020) menegaskan bahwa, itu berasal dari proses alami. Yang, X. et al., (2020) investigasi telah menunjukkan bahwa beberapa SARSr-CoV kelelawar memiliki kemungkinan untuk menginfeksi manusia. Berdasarkan laporan World Health Organisation (2020) penyakit virus COVID-19 adalah penyakit menular yang disebabkan oleh virus korona yang baru ditemukan yang mempengaruhi orang dengan cara yang berbeda. Gejala umumnya termasuk demam, batuk kering, kelelahan, sesak napas, nyeri dan nyeri, sakit tenggorokan, dan sangat sedikit orang yang melaporkan diare, mual atau pilek (Inayah et al., 2020).

Virus ini dapat menyebar melalui tetesan kecil (droplet) dari hidung atau mulut pada saat batuk atau bersin (Suharmanto, 2020). Droplet tersebut kemudian jatuh pada benda di sekitarnya. Kemudian, jika ada orang lain menyentuh benda yang sudah terkontaminasi dengan droplet tersebut, lalu orang itu menyentuh mata, hidung atau mulut (segitiga wajah), maka orang itu dapat terinfeksi COVID-19. Selain itu, seseorang bisa terinfeksi COVID-19 saat tanpa sengaja menghirup droplet dari penderita. Gejala yang ditimbulkan yaitu demam, batuk, dan napas yang pendek. The Center for Disease Control and Prevention (2020) percaya bahwa pasien COVID-19 dapat mengalami gejala-gejala ini dari 2 hari sampai 14 hari setelah terpapar virusnya.

Menanggani kasus COVID-19 ini yang semakin mengkhawatirkan, pemerintah Indonesia menerbitkan protokol Kesehatan yang diterapkan di seluruh wilayah Indonesia dengan dipandu secara terpusat oleh Kementrian Kesehatan Telaumbanua, D. (2020). Selain itu, dalam menangani kasus tersebut harus dilakukan oleh seluruh aspek yang terdapat dalam lapisan masyarakat. Mulai dari pemerintah hingga masyarakat. Konsekuensi yang harus diterima oleh masyarakat dengan diberlakukannya prototokol kesehatan adalah ditutupnya berbagai fasilitas publik dengan tujuan mengurangi intensitas komunikasi fisik yang akan menimbulkan potensi penyebaran COVID-19.

Sekolah sebagai lembaga pendidikan formal menjadi salah satu fasilitas umum yang harus menghentikan segala akitivitas pembelajaran secara tatap muka. Melalui Surat Edaran Menteri Pendidikan dan Kebudayaan Republik Indonesia Nomor 4 Tahun 2020 tentang Pelaksanaan Pendidikan dalam Masa Darurat Coronavirus Disease (COVID-19) ada beberapa aturan mengenai proses pembelajaran di sekolah yaitu:

1. Belajar dari Rumah melalui pembelajaran daring/jarak jauh dilaksanakan untuk memberikan pengalaman belajar yang bermakna bagi siswa, tanpa terbebani tuntutan menuntaskan seluruh capaian kurikulum untuk kenaikan kelas maupun kelulusan

2. Belajar dari Rumah dapat difokuskan pada pendidikan kecakapan hidup antara lain mengenai pandemi COVID-19

3. Aktivitas dan tugas pembelajaran Belajar dari Rumah dapat bervariasi antarsiswa, sesuai minat dan kondisi masing-masing, termasuk mempertimbangkan kesenjangan akses/fasilitas belajar di rumah

4. Bukti atau produk aktivitas Belajar dari Rumah diberi umpan balik yang bersifat kualitatif dan berguna dari guru, tanpa diharuskan memberi skor/nilai kuantitatif. (Kementerian Pendidikan dan Kebudayaan Republik Indonesia, 2020).

Berlandaskan pada surat edaran tadi maka proses pembelajaran siswa di sekolah saat ini berubah menjadi metode pembelajaran jarak jauh, sehingga pihak sekolah, siswa dan orangtua harus bekerja sama untuk dapat menyelenggarakan proses pembelajaran yang baik. Di SMA Negeri 3 Batam

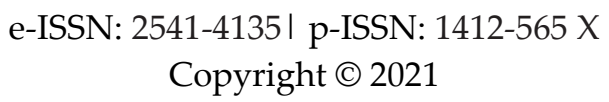


sendiri menerapkan pembelajaran jarak jauh sesuai dengan Surat Edaran Kepala Dinas Pendidikan Provinsi Kepri B/420/268.1/DISDIK/2020 Tentang Pedoman Penyelenggaraan Belajar Dari Rumah Dalam Masa Darurat Penyebaran Corona Virus Disease (COVID-19) (BatamNews, 2020).

Adanya himbauan tersebut mengharuskan pendidik dan peserta didik untuk mampu berdaptasi dengan pola pendidikan digital yang belum pernah dilakukan sebelumnya, akibat hal tersebut banyak peserta didik mengalami kesulitan belajar. Hal ini dibuktikan dengan adanya hasil survey oleh Saiful Mujani Research and Consulting (SMRC) bahwa dari 2201 respon siswa, 92\% diantaranya merasa sangat banyak atau cukup banyak mempunyai masalah yang mengganggu selama pembelajaran online (Saiful Mujani Research \& Consulting, 2020). Menanggapi hal tersebut, diperlukan inovasi untuk menghadirkan sumber belajar digital yang mampu diakses secara mudah oleh seluruh siswa.

Dalam proses pembelajaran, sumber belajar memainkan peran penting dalam meningkatkan pemahaman siswa terhadap materi. Sumber belajar sendiri dapat dimaknai sebagai suatu sistem yang terdiri atas sekumpulan bahan atau situasi yang dikumpulkan secara sengaja dan dibuat agar memungkinkan peserta didik belajar secara individual Syukur, F. (2008). Adapun sumber belajar kemudian oleh Sudjana, N. (1989) dapat dibagi ke dalam beberapa kategori sebagai berikut:

1. Sumber belajar cetak, terdiri dari: buku, majalah, ensiklopedi, brosur, koran, poster, denah, dan lain-lain.

2. Sumber belajar non-cetak, terdiri dari: film, slide, video, model, audio kaset, dan lain-lain.

3. Sumber belajar yang berupa fasilitas, terdiri dari auditorium, perpustakaan, ruang belajar, studio, lapangan olahraga, dan lain-lain.

4. Sumber belajar berupa kegiatan, terdiri dari wawancara, kerja kelompok, observasi, simulasi, permainan, dan lain-lain.

5. Sumber belajar berupa lingkungan, terdiri dari taman, museum, dan lain-lain.

Sumber belajar merupakan hal vital dalam proses pembelajaran, karena sebaik apapun materi yang diberikan oleh guru di ruang kelas tidak akan mencukupi pemahaman siswa terhadap materi pelajaran. Diperlukan sumber belajar lainnya untuk memfasilitasi siswa mendapatkan pengetahuan yang lebih komprehensif. Sebagaimana yang dijelaskan oleh Sumiati dan Asra (2008), bahwa yang krusial dalam proses pembelajaran selain pada kompetensi pendidik, juga dipengaruhi oleh ketersediaan sumber belajar yang memadai. Semakin banyak sumber belajar yang disediakan oleh sekolah, maka semakin besar pula peluang meningkatnya pemahaman.

Pengembangan fasilitas sumber belajar siswa saat ini harus diselaraskan dengan perkembangan teknologi modern. Hal ini dilandasi alasan sosiologis di mana pola perilaku dan kecenderungan manusia akan kian berubah mengikuti perkembangan teknologi. Tidak hanya faktor sosiologis, faktor keadaan tidak terduga juga dapat menjadi alasan kenapa fasilitas sumber belajar harus selaras dengan perkembangan teknologi. Seperti saat ini, pandemi COVID-19 yang mengharuskan seluruh lembaga pendidikan untuk melaksanakan pembelajaran daring. Dengan dilaksanakannya pembelajaran secara daring, otomatis sumber belajar berupa perpustakaan di sekolah harus ditutup bersamaan dengan diberlakukannya aturan pembelajaran jarak jauh.

Menghadirkan perpustakaan digital di sekolah merupakan langkah solutif untuk mengatasi masalah kesulitan siswa dalam mengakses sumber belajar yang mana masalah tersebut dapat menghambat pemahaman siswa terhadap materi yang sedang dipelajari. Khususnya dalam kondisi pandemi seperti saat ini yang menuntut proses pembelajaran dilaksanakan secara daring, sumber belajar menjadi kebutuhan vital bagi peserta didik mengingat terbatasnya gerak seorang pendidik dalam menyampaikan materi. Oleh sebab itu, menghadirkan perpustakan digital di sekolah dapat menjadi langkah baik dalam memaksimalkan tercapainya tujuan belajar. 
Peran penting perpustakaan digital dalam meningkatkan kualitas peserta didik telah dibuktikan oleh Hikamudin et al., (2019) dalam penelitiannya yang menjelaskan telah terjadi peningkatan Keterampilan Berpikir Tingkat Tinggi (KBTT) pada siswa yang awalnya tingkat kelulusan hanya 42.5\% menjadi $87.5 \%$. Purwanti, R. (2017) dalam penelitiannya juga menemukan pengaruh signifikan kategori tinggi antara perpustakaan digital terhadap peningkatan tingkat pengetahuan peserta didik di SMA Negeri 4 Bandung. Penelitian yang dilakukan oleh Ladan, A. et al., (2020) bagaimana peran perpustakaan berganti dari pelayanan secara tatap muka berganti menjadi layanan daring melalui sosial media untuk tetap terjangkau kepada pemustaka.

Pembelajaran dalam kondisi apapun tetap memiliki esensi tujuan yang sama, yaitu meningkatkan kualitas peserta didik. Kondisi pandemi yang mengharuskan pembelajaran dilaksanakan secara daring tidak boleh menghilangkan esensi tujuan tersebut, maka perlu adanya solusi alternatif yang dapat menunjang ketercapaian belajar dengan menyediakan fasilitas sumber belajar yang efektif dan efisien bagi siswa berupa perpustakaan digital. Atas dasar pemikiran tersebut peneliti tertarik untuk meneliti bagaimana optimalisasi penggunaan perpustakaan digital dalam menunjang proses pembelajaran jarak jauh. Adapun sekolah yang peneliti pilih adalah SMAN 3 Batam yang didasarkan pada pertimbangan bahwa sekolah ini sebelumnya belum memiliki akses perpustakaan digital. Oleh sebab itu, diharapkan dengan adanya penelitian ini dapat menunjang terbentuknya perpustakaan digital sekolah yang mampu memudahkan peserta didik dalam mengakses sumber belajar. Hasil penelitian ini diharapkan dapat bermanfaat bagi guru, kepala sekolah, dinas pendidikan selaku pemangku kebijakan, akademisi serta masyarakat luas dalam hal pengembangan media pembelajaran, sumber belajar elektronik dan kajiam keilmuan ilmu perpustakaan informasi.

\section{METODE PENELITIAN}

Analisis pemanfaatan perpustakaan digital sebagai sumber belajar dalam penelitian ini adapun data awal dalam penelitian ini diperoleh dengan menyebarkan kuisioner kepada kepada 67 siswa. Kuisioner tersebut disebar dalam bentuk google form kepada siswa melalui perantara guru di sekolah tersebut. Selanjutnya responden mengisi kuisioner tersebut sesuai dengan apa yang mereka rasakan selama proses belajar mengajar. Penelitian ini dilaksanakan di Sekolah Menengah Atas Negeri (SMAN) 3 Batam dengan siswa sebagai subjek penelitian. Pendekatan yang digunakan dalam penelitian ini adalah pendekatan dengan metode design and development (D\&D) berdasarkan pernyataan Richey, R. C., \& Klein, J. D. (2014) desain dan pengembangan merupakan studi sistematis dari proses desain, pengembangan dan evaluasi dengan tujuan membangun dasar empiris untuk penciptaan produk dan alat instruksional dan non-instruksional dan model baru atau yang disempurnakan yang mengatur perkembangannya. Dalam konteks penelitian ini, produk yang dikembangkan ialah perpustakaan digital.

\section{HASIL DAN PEMBAHASAN Hasil}

Data yang diperoleh dari kuisioner yang diberikan kepada 67 siswa SMA Negeri 3 Batam, penelitian ini mengungkapkan bagaimana permasalahan sumber belajar saat pembelajaran jarak jauh, pemanfaatan kuota belajar, dan kendala pada pembelajaran jarak jauh. Kemudian peneliti melihat hasil tersebut mengembangkan perpustakaan digital sebagai sumber belajar siswa SMA Negeri 3 Batam Respon Siswa terhadap Kendala Proses Pembelajaran Daring dapat dilihat pada gambar 1. 


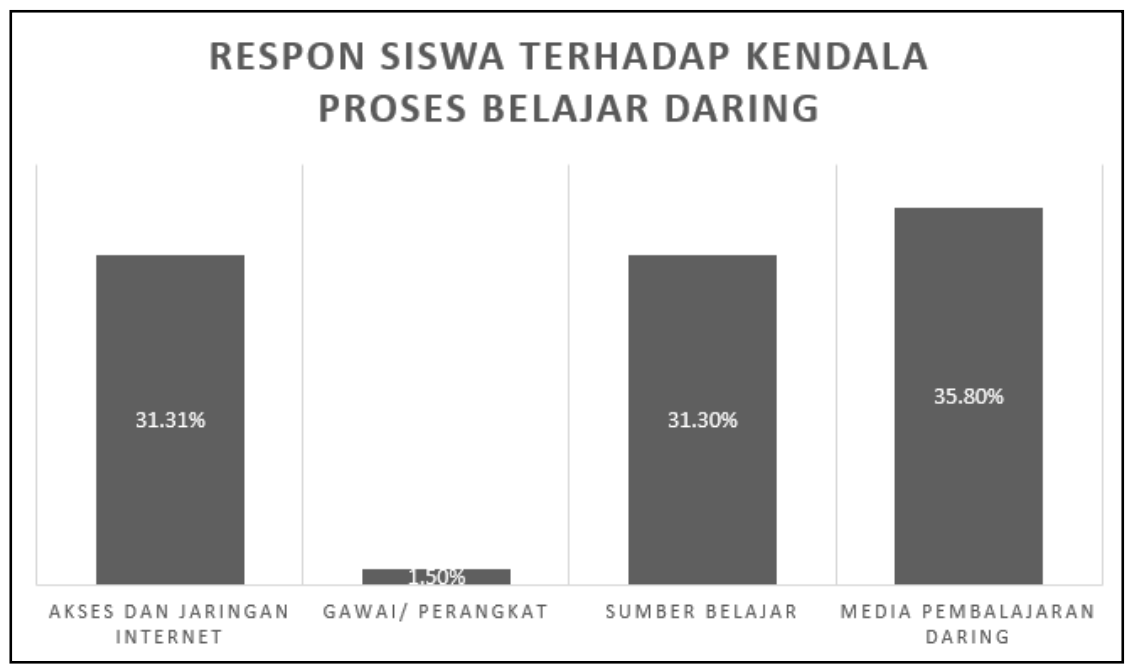

Gambar 1. Diagram Respon Siswa terhadap Kendala Proses Pembelajaran Daring

Berdasarkan data pada gambar 1 terlihat bahwa kendala pada proses pembelajaran daring siswa di SMA Negeri 3 adalah media pembelajaran dengan 35.80\% lalu akses dan jaringan internet dan sumber belajar masing-masing $31.30 \%$ dan gawai atau perangkat sebesar $1.50 \%$. Menurut Simonson M dalam Nurfadillah \& Ardiansah (2021) pembelajaran jarak jauh atau pembelajaran daring adalah salah satu bagian dari pendidikan jarak jauh yang secara khusus menggunakan gabungan teknologi elektronik dan teknologi dengan basis internet. Berdasarkan data diatas selaras dengan pernyataan Aji, R.H.S. (2020) bahwa pada proses pembelajaran daring terdapat kendala yaitu keterbatasan penguasaan teknologi informasi oleh guru sehingga penyampaian pembelaran dengan pemanfaatan teknologi agak terkendala, lalu sarana dan prasarana yang tidak memadai sehingga menjadi kendala, lalu akses internet, dan yang terakhir adalah anggaran untuk efektivitas proses pembelajaran.

Berdasarkan Statistik Pemanfaatan Sumber Buku Elektronik oleh Siswa SMAN 3 Batam, terdapat sebanyak $60 \%$ responden menyatakan tidak memanfaatkan sumber buku elektronik yang disediakan oleh Perpusnas dan Kemendikbud pada proses pembelajaran. Data tersebut dapat dilihat pada gambar 2.

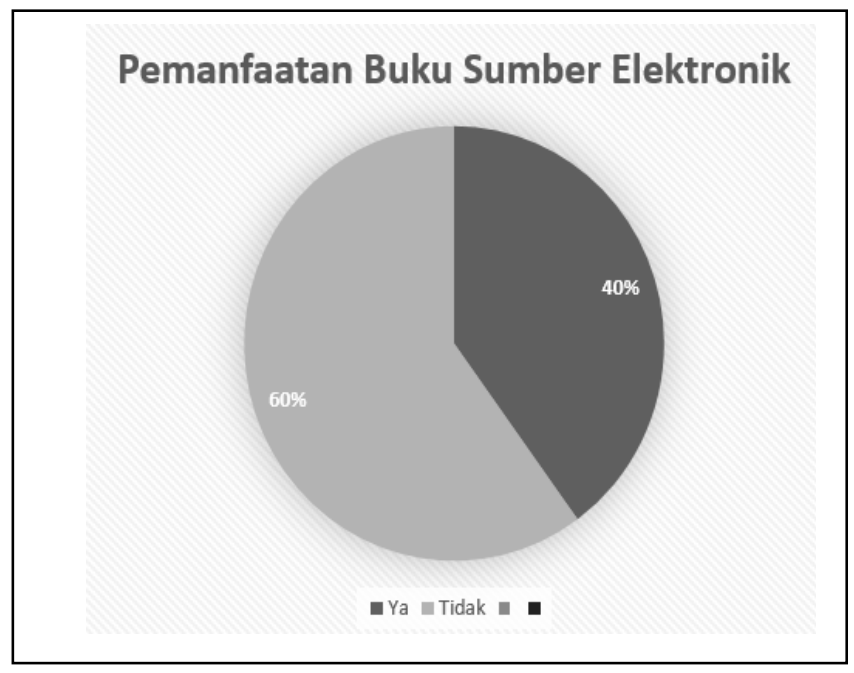

Gambar 2. Statistik Pemanfaatan Sumber Buku Elektronik oleh Siswa SMAN 3 Batam

$$
\text { e-ISSN: 2541-4135 I p-ISSN: 1412-565 X }
$$

Copyright (C) 2021 
Dengan beralihnya metode pembelajaran dari tatap muka ke pembelajaran daring membuat akses sumber pustaka menjadi terkendala. Melihat data tersebut perpustakan sekolah harus memberikan layanan digital dan sumber digital kepada pemustaka sekolah dalam hal ini guru dan siswa sekolah. Koleksi perpustakaan menjadi salah satu sumber belajar yang diperlukan oleh civitas academica. Koleksi-koleksi yang ada di perpustakaan digunakan untuk bahan ajar yang mendukung proses pembelajaran di kelas (Yuliani, T., \& Nugraha, H., 2021). Menurut Suharti, A. (2020) untuk mencegah penyebaran COVID-19 Dalam rangka menyediakan sumber-sumber informasi yang dibutuhkan dalam pembelajaran dan perkuliahan diperlukan sumber-sumber informasi yang dapat diakses secara online. Sumber-sumber informasi online tersebut dikenal dengan sumber informasi digital. Melalui sumber informasi digital ini, pemustaka dapat mengakses koleksi digital yang dimiliki perpustakaan dari mana saja dan kapan saja.

Seiring dengan pemberlakuan pembelajaran daring maka sumber belajar peserta didik juga terjadi perubahan dari sumber cetak menjadi elektronik, pemberian kuota internet dari pemerintah kepada peserta didik untuk akses sumber belajar hanya sebagai fasilitas penunjang pembelajaran daring, tidak signifikan terhadap sumber belajar siswa, dukungan akses internet seharusnya dimanfaatkan dengan sebaik mungkin oleh pendidik dan peserta didik. Banyak laman yang menyediakan referensi digital, namun sumbernya tidak kredibel berbasis blog bebas. Beberapa negara di dunia untuk memastikan keberlanjutan pendidikan dimasa pandemi COVID-19 mereka menerapkan beberapa kebijakan seperti negera bagian New South Wales di Australia memberikan peminjaman laptop kepada siswa, lalu seperti Inggris Raya dan Jepang mereka memberikan modul kepada siswa berbentuk tercetak kepada siswa dan Meksiko yang melakukan siaran pendidikan melalui saluran televise. (Gouëdard et al., 2020)

Melihat dari kebijakan dibeberapa negara di dunia peneliti menginisiasi untuk perancangan perpustakaan digital berbasis website. Urgensi pelayanan perpustakaan secara daring dilakukan untuk memberikan sumber belajar kredibel kepada siswa sekolah. Perpustakaan digital dan sumber elektronik sangat membantu pemerolehan informasi untuk sumber belajar di masa pandemi COVID-19. Perpustakaan sekolah berinovasi untuk tetap memberikan pelayanan walaupun secara daring.

\section{Pembahasan}

Pandemi COVID-19 telah mendistrupsi semua aktivitas manusia, pembatasan sosial masyrakat diberlakukan di Indonesia. Implikasi dari pembatasan sosial ini pemerintah mengeluarkan kebijakan untuk menutup beberapa tempat aktivitas masyarakat salah satunya ialah instutusi pendidikan seperti sekolah dan universitas (Reimers, F. et al., 2020). Di tutupnya sekolah membuat proses pembelajaran bermigrasi dari tatap muka menjadi pembelajaran daring seperti yang terjadi di Indonesia. (Wahyono, P. et al., 2020). Dengan terjadinya perubahan secara signifikan ini membuat semua pihak terlihat gagap dalam menjalankannya dan terjadi kendala dalam proses belajar mengajar. Kendala dalam proses belajar daring berdasarkan data pada tabel 1 terlihat bahwa kendala pada proses pembelajaran daring siswa di SMA Negeri 3 adalah media pembelajaran dengan 35.80\% lalu akses dan jaringan internet dan sumber belajar masing-masing $31.80 \%$ dan gawai atau perangkat sebesar $1.50 \%$. Pada hasil ini menunjukan media pembelajaran mendapatkan respon tinggi terhadap kendala belajar siswa di SMA Negeri 3 Batam. Berdasarkan hasil penelitian yang dilakukan oleh Putri R.S. et al., (2020) menunjukan media pembelajaran menjadi permasalahan dalam proses belajar mengajar, dikarenakan guru dan siswa tidak terbiasa memanfaatkan media pembelajaran secara daring sebelum ini, terjadi perubahan secara siginifikan terhadap pembelajaran yang biasanya digunakan, oleh karena itu mereka menyarakan untuk 
membiasakan bersosialisasi melalui media daring, siswa membutuhkan waktu untuk beradaptasi dengan pembelajaran jarak jauh, dan dibutuhkan lebih banyak upaya guru daripada kelas tatap muka biasa untuk membangun pemahaman siswa.

Permasalahan sumber belajar siswa menempati urutan ketiga dengan $31.30 \%$ responden dalam tabel 1 permasalahan pembelajaran daring di SMA Negeri 3 Batam. Kemudian secara rinci pada tabel 2 sebanyak $60 \%$ responden tidak memanfaatkan buku elektronik yang diberikan Perpusnas dan Kemendikbud pada proses belajar mengajar. Berdasarkan laporan Schleicher, A. (2020) beberapa negara menggunakan berbagai sumber daya untuk mendukung pembelajaran siswa saat mereka tidak dapat datang ke sekolah, termasuk paket instruksional (buku teks, lembar kerja dan cetakan), pendidikan radio, televisi pendidikan, dan sumber daya instruksional daring. Di Indonesia juga telah diterapkan kebijakan serupa kerjasama antara Kemendikbud dengan LPP TVRI memberikan materi pembelajaran kepada siswa sekolah dari usia dini hingga tingkat SMA. (Liputan6, 2020; Pramita, E.W., 2020). Tetapi dengan adanya penyiaran dari TVRI tentang materi belajar siswa, mereka tidak dapat mengeksplorasi secara komprehensif sumber belajar dan terbatas dengan waktu yang telah ditentukan oleh pihak TVRI

Oleh karena itu pemanfaatan perpustaakaan dijangka perlu untuk membantu siswa dalam mendapatkan sumber belajar yang komprehensif kepada siswa SMA Negeri 3 Batam. Menurut Akviansah, M. D., \& Sariyatun. (2020) perpustakaan di sekolah berperan sebagai penunjang pembelajaran. Selain sebagi penunjang, perpustakaan juga berperan sebagai sumber belajar. Sumber belajar disini maksudnya yakni semua bahan atau sumber informasi, sumber alat, sumber peraga yang dapat digunakan dalam proses pembelajaran. Sebelum pandemi COVID-19, sebagian besar perpustakaan Indonesia menawarkan layanan tradisional secara fisik, pengguna harus datang ke ruang baca jika ingin membaca buku dan menuju meja sirkulasi jika ingin meminjam.koleksi. (Winata A. P. et al., 2021). Setelah dikeluarkan kebijakan pembatasan aktivitas masyarakat sehingga impilikasinya terhadap sekolah, membuat perpustakaan sekolah tidak dapat memberikan pelayanan secara tatap muka. Dengan pemanfaatan teknologi informasi pelayanan perpustakaan dapat bertransformasi dari layanan secara langsung dapat berupa pelayanan maya atau daring. Akviansah, M. D., \& Sariyatun).

Berdasarkan Undang-Undang Nomor 43 tahun 2007 tentang Perpustakaan pasal 14 ayat 3 menyatakan bahwa "Setiap perpustakaan mengembangkan layanan perpustakaan sesuai dengan kemajuan teknologi informasi dan komunikasi." Selain itu, Pemanfaatan Teknologi Informasi juga disampaikan pada pasal 12 ayat 1 yang menyatakan bahwa "Koleksi perpustakaan diseleksi, diolah, disimpan, dilayankan, dan dikembangkan, sesuai dengan kepentingan pemustaka dengan memperhatikan perkembangan teknologi informasi dan komunikasi.",

Menurut Johan et al., (2020) kedua pasal ini menjadi landasan bagi pelayanan perpustakaan memanfaatkan teknologi informasi Kemudian menurut Firman dkk dalam Johan et al., (2020) pemanfaatan teknologi informasi di perpustakaan meliputi beberapa hal diantaranya yaitu, pemanfaatan untuk sistem informasi perpustakaan atau lebih dikenal dengan otomasi perpustakaan, pemanfaatan untuk pengelolaan dan layanan koleksi digital yang dikenal dengan perpustakaan digital, dan pemanfaatan untuk sarana promosi pemasaran layanan perpustakaan. Informasi yang ditampilkan dan disajikan dapat berubah seiring jalannya waktu sehingga informasi yang disajikan tidak ketinggalan zaman atau terlambat. Kemudahan ini yang membuat website sebagai sarana informasi yang digemari user saat ini.

Peneliti melihat hasil kuisioner dan apa yang terjadi di SMA Negeri 3 Batam kemudian berinisasi untuk merancang sebuah perpustakaan digital berbasis website yang kemudian bekerjasama dengan pihak perpustakaan sekolah SMA Negeri 3 Batam pada perencanaan dan pengembangannya. Kemajuan teknologi informasi dan komputer menawarkan peluang untuk mengefisiensi pekerjaan

$$
\begin{gathered}
\text { e-ISSN: } 2541-4135 \text { । p-ISSN: } 1412-565 \text { X } \\
\text { Copyright } @ 2021 \\
42
\end{gathered}
$$


khususnya di perpustakaan. Perpustakaan sebagai institusi pengelola informasi merupakan salah satu bidang penerapan teknologi informasi yang berkembang dengan pesat. Salah satu fitur yang dapat dikembangkan dalam bidang perpustakaan adalah pengembangan perpustakaan digital berbasis web. Pemanfaatan web site memberi kemudahan akan akses informasi yang lebih cepat baik dari dalam maupun dari luar perpustakaan.(Mahedy, K. S., 2009). Diharapkan peranangan perpustakaan digital ini dapat memudahkan siswa dan guru SMA Negeri 3 Batam dalam mengakses sumber belajar elektronik serta referensi yang kredibel. Merancang suatu perpustakaan digital sebagai media sumber beajar yang dapat dimanfaatkan oleh siswa dalam proses pembelajaran dimaksudkan agar siswa dapat meningkatkan pemahamannya terhadap materi yang diajarkan dalam kondisi pembelajaran daring. Awal pembuatan perpustakaan digital ini adalah menentukan sumber belajar apa yang cocok dan tepat untuk memfasilitasi proses belajar siswa. Selanjutnya dilanjutkan dengan merancang tampilan awal website perpustakaan digital yang sederhana, namun dapat menarik minat siswa. Adapun tampilan awal perpustakaan digital yang telah dirancang dapat dilihat sebagai berikut:

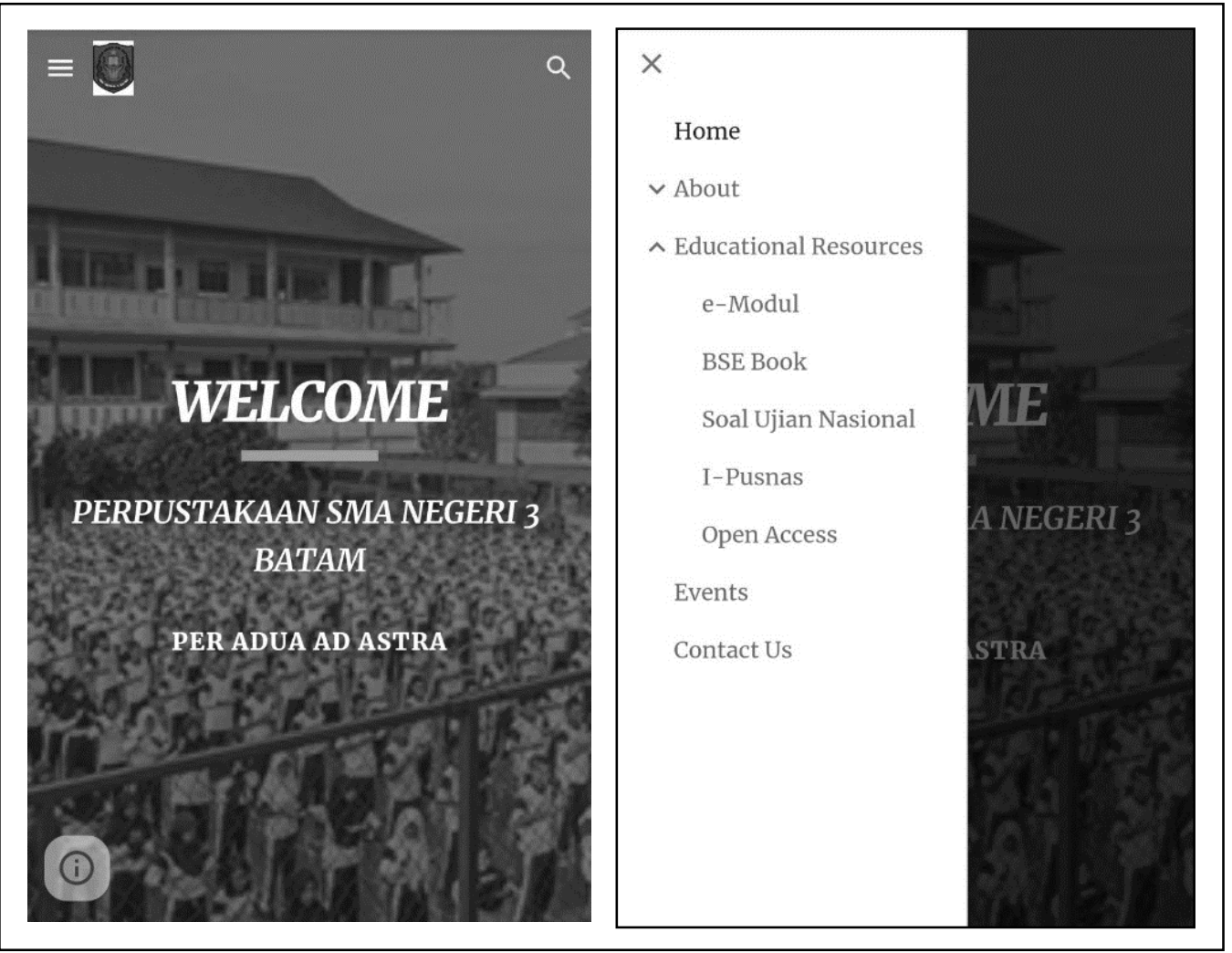

Gambar 3. Tampilan Perpustakaan Digital SMA Negeri 3 Batam

Pada gambar 3. dapat dilihat tampilan menu yang oleh peneliti desain untuk menghadirkan berbagai sumber belajar yang relevan. Pada proses perencanaannya penulis berkonsultasi dengan pihak perpustakaan untuk perkiraan fitur apa saja yang akan ditampilkan dan layanan yang diberikan di perpustakaan digital ini. Peneliti mengembangkan perpustakaan digital dengan memanfaatkan Google Sites sebagai platform. Google Sites merupakan sebuah produk dari Google yang pakai untuk kebutuhan pendidikan yang dimanfaatkan untuk membuat website baik itu website personal, kelompok atau perusahaan. (Firdaus et al., 2021) Terdapat beberapa kemudahan dalam pemanfaatan Google Sites yaitu bisa digunakan secara gratis tanpa harus mengeluarkan biaya, memungkinkan pengguna untuk

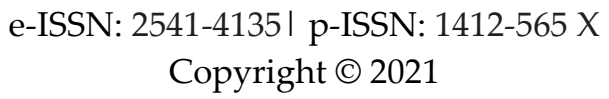


berinteraksi dengan halaman Google Sites dan bisa diakses dengan berbagai perangkat selama terkoneksi dengan internet (Firdaus et al., 2021).

Setelah mendapatkan umpan balik dari pihak perpustakaan sekolah, peneliti menciptakan fitur Educational Resources untuk sumber belajar elektronik. Terdapat beberapa fitur dalam menu perpustakaan digital yang penulis rancang, pertama fitur $e$-Modul merupakan fitur yang menyajikan berbagai bahan materi pelajaran dari berbagai mata pelajaran dalam bentuk modul singkat. Fitur kedua, yaitu fitur BSE Book yang berisikan berbagai buku terbitan Kemendikbud dalam bentuk soft file yang dapat diunduh secara gratis. Fitur BSE Kemendikbud dapat dilihat pada gambar 4.

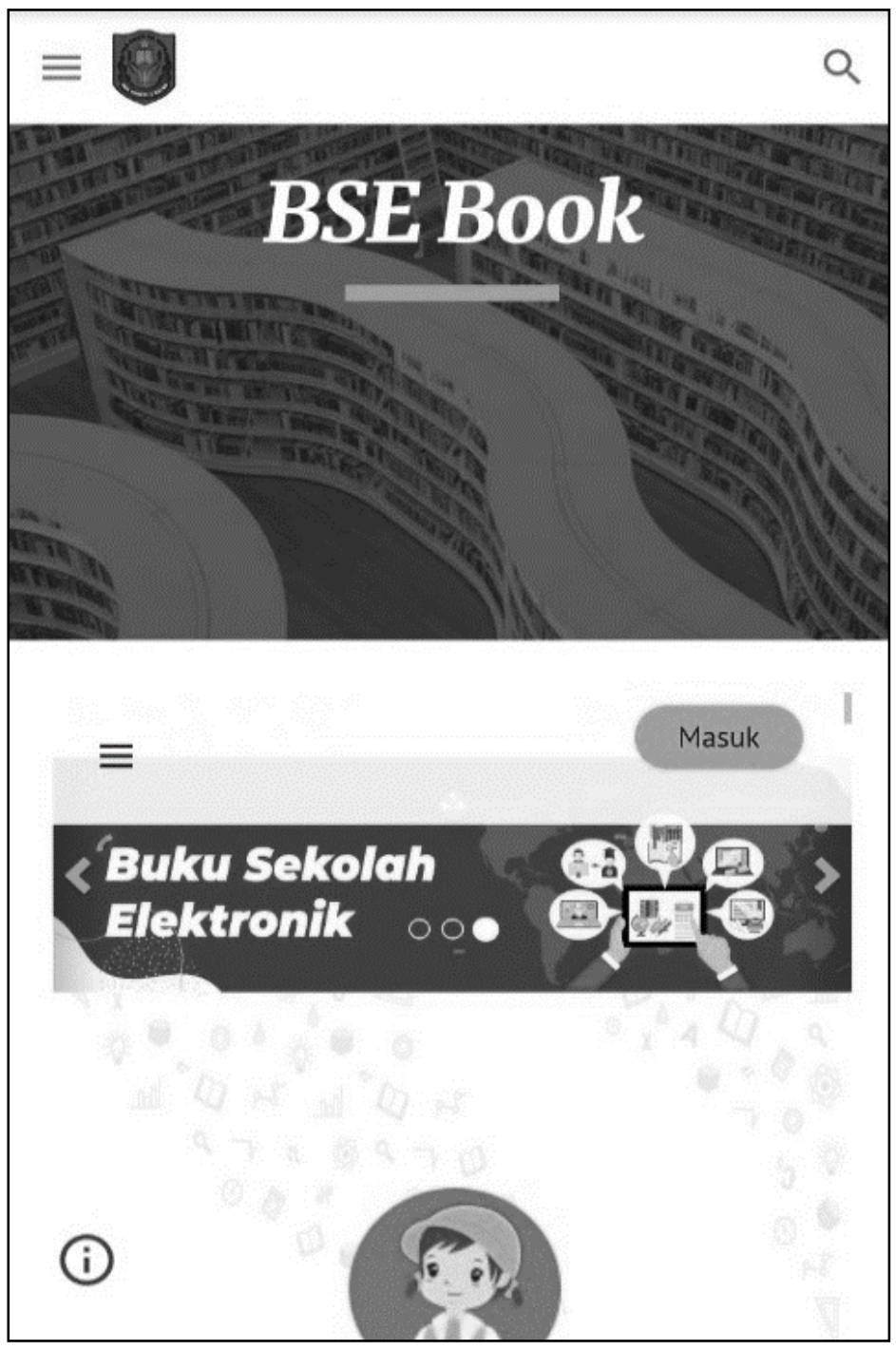

Gambar 4. Fitur BSE Kemendikbud

Fitur ketiga ialah fitur soal ujian nasional yang berisikan kumpulan berbagai soal ujian nasional dari tahun-tahun sebelumnya. Fitur ini dikhususkan pada siswa kelas XII untuk mempersiapkan diri mengahdapi ujian nasional. Terakhir terdapat fitur I-Pusnas yang berisikan berbagai buku elektronik yang dapat diakses secara daring oleh siswa guna menunjang sumber belajar dari buku teks utama. Tampilan fitur ini dapat dilihat pada gambar 5. 


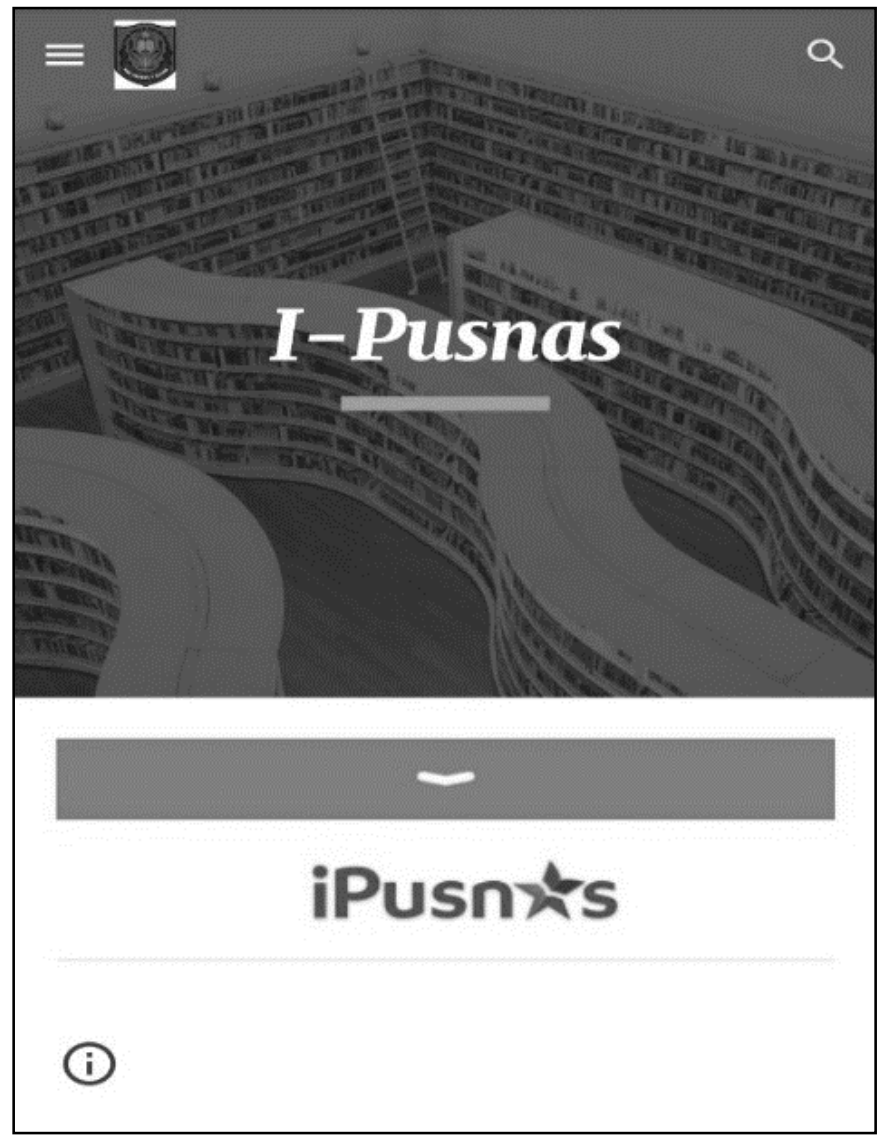

Gambar 5. Sumber Belajar Elektronik i-Pusnas

Proses pembuatan perpustakan digital tidak berjalan mulus begitu saja, melainkan terdapat beberapa kendala yang peneliti temui. Kendala pertama berkaitan dengan pengetahuan peneliti yang masih terbatas terutama dalam perancangan web sehingga dalam pembuatan perpustakan digital ini memakan waktu yang cukup lama. Selain itu, dibutuhkan waktu yang cukup lama pula bagi peneliti untuk mencari dan menyeleksi berbagai bahan sumber belajar yang akan dimasukan dalam perpustakaan digital yang telah dirancang.

Pada kondisi pandemi COVID-19 yang mengharuskan pembelajaran dilaksanakan secara daring tentunya membuat kehadiran perpustakaan digital menjadi daya dongkrak lebih untuk meningkatkan hasil belajar siswa. Pepustakaan digital yang dirancang oleh peneliti setidaknya memiliki beberapa kelebihan sebagai berikut:

1. Dapat diakses kapanpun dan dimanapun oleh peserta didik dan guru

2. Menyediakan sumber belajar dan informasi sesuai kebutuhan warga sekolah

3. Mudah dalam pengaturan bagi pihak perpustakaan sekolah.

Pengembangan suatu produk tertentu selain memiliki kelebihan, juga tidak bisa dipungkiri bahwa ia memiliki kekurangan pula. Termasuk juga perpustakaan digital yang telah dirancang dan dikembangkan oleh peneliti memiliki beberapa kekurangan, seperti tidak memiliki repository tersendiri. Terlepas dari kekurangan yang dimiliki, hadirnya perpustakaan digital sekolah merupakan suatu inovasi yang harus dikembangkan guna memfasilitasi siswa dalam memperoleh sumber belajar. 


\section{KESIMPULAN}

Pandemi COVID-19 telah membawa perubahan signifikan pada kehidupan manusia pada pembelajaran dan pengajaran di dunia pendidikan, termasuk di Indonesia. Masalahnya, pembelajaran jarak jauh atau pembelajaran daring belum menjadi bagian yang biasa di sekolah-sekolah di Indonesia. Sekolah pada umumnya mengandalkan pembelajaran tatap muka, lembaga pendidikan di Indonesia sangat terpengaruh oleh peralihan metode pembelajaran ini ke pembelajaran daring di rumah. Beralih ke pembelajaran daring di rumah bahkan lebih sulit di sekolah dasar karena siswa muda umumnya membutuhkan lebih banyak bantuan dalam pembelajaran mereka. Kondisi tersebut menimbulkan ketegangan antara sekolah dan rumah. Di pihak sekolah, para guru berjuang dengan perubahan tersebut dengan harus mendalami teknologi informasi untuk media pembelajaran, lalu perangkat sekolah seperti perpustakaan sekolah harus berinovasi untuk memberikan pelayanan kepada siswa secara daring. Di rumah, orangtua harus siap menyediakan perangkat dan jaringan internet. Permasalahan sumber belajar menjadi perhatian pihak sekolah dan orangtua untuk menunjang efektivitas belajar siswa dirumah, dengan pemanfaatan pelayan perpustakaan berbasis teknologi informasi, siswa dapat merndapatkan sumber belajar elektronik dan referensi dengan mudah dan dapat diakses pada kapanpun dan dimanapun.

\section{DAFTAR PUSTAKA}

Aji, R. H. S. (2020). Dampak Covid-19 pada Pendidikan di Indonesia: Sekolah, Keterampilan, dan Proses Pembelajaran. SALAM: Jurnal Sosial Dan Budaya Syar-I, 7(5). https://doi.org/10.15408/sjsbs.v7i5.15314

Akviansah, M. D., \& Sariyatun. (2020). Perpustakaan Maya sebagai Sumber Belajar dan Penunjang Pembelajaran IPS secara Daring di Era Pandemi COVID-19. Jurnal Teori Dan Praksis Pembelajaran IPS, 5(2), 92-102.

Andersen, K. G., Rambaut, A., Lipkin, W. I., Holmes, E. C., \& Garry, R. F. (2020). The proximal origin of SARS-CoV-2. Nature Medicine, 26(4), 450-452. https://doi.org/10.1038/s41591020-0820-9

BatamNews. (2020). Pemerintah Perpanjang Libur Darurat Corona untuk SMA dan SMK di Kepri.

Firdaus, R., Unik, M., Wenando, F. A., \& Fitri, D. A. (2021). Pemanfaatan Google Sites Untuk Penerimaan Peserta Didik Baru Bagi Madrasah Se-Riau. Jurnal Pengabdian UntukMu NegeRI, 5(1), 69-73. https://doi.org/10.37859/jpumri.v5i1.2381

Gouëdard, P., Pont, B., \& Viennet, R. (2020). EDUCATION RESPONSES TO COVID-19: IMPLEMENTING A WAY FORWARD OECD.

Hikamudin, M. I., Hartati, T., Agustin, M., Prawiyogi, A. G., \& Fauzan, A. (2019). Peningkatan Literasi Perpustakaan Digital Melalui Pembelajaran Keterampilan Berpikir Tingkat Tinggi di Sekolah Dasar. Edulib, 9(1), 12-25. https://doi.org/10.17509/edulib.v9i1.15566

Inayah, I., Buana, R., Fikri, R., \& Marhamah. (2020). Studi Literatur Review: Gambaran Gejala dan Diagnosis Keperawatan di Pelayanan Klinik, Rumah Sakit, dan Komunitas pada Pasien Covid-19. Prosiding Pertemuan Ilmiah Nasional Penelitian \& Pengabdian Masyarakat II “Tantangan Dan Inovasi Kesehatan Di Era Society 5.0,” 141-145.

Johan, R. C., Margana, H. H., Damayanty, Santika, S., Yogaswara, T. A., \& Wulandari, Y. (2020). Optimalisasi Layanan Dalam Jejaring Perpustakaan UPI Masa Bencana Covid-19. Edulib, 10(1), 84-99. https://doi.org/10.17509/edulib.v10i1.24288

Kementerian Pendidikan dan Kebudayaan Republik Indonesia. (2020). Surat Edaran Pelaksanaan Kebijakan Pendidikan dalam Masa Darurat Penyebaran Coronavirus Disease(Covid-19). 
Ladan, A., Haruna, B., \& Madu, A. U. (2020). COVID-19 Pandemic and Social Media News in Nigeria: The Role of Libraries and Library Associations in Information Dissemination. International Journal of Innovation and Research in Educational Sciences, 7(2), 2349-5219.

Liputan6. (2020). TVRI Siarkan Program Belajar bagi Siswa Selama Pandemi Covid-19 - News Liputan6.com. Liputan6.

Mahedy, K. S. (2009). Pengembangan Perpustakaan Digital Berbasis Web di Perpustakaan Jurusan Pendidikan Dasar Universitas Pendidikan Ganesha. JPTK Undiksha, 6(1), 51-62.

Nurfadillah, M., \& Ardiansah. (2021). Perilaku Pencarian Informasi Mahasiswa Dalam Memenuhi Kebutuhan Informasi Sebelum dan Saat Pandemi COVID-19. FIHRIS: Jurnal Ilmu Perpustakaan Dan Informasi, 16(1), 21-39.

Pramita, E. W. (2020, April). Alternatif Belajar dari Rumah Melalui Siaran TVRI, Ada Materi dan Film - Cantik Tempo.co. TEMPO.

Purwanti, R. (2017). Pengaruh Perpustakaan Digital dan Gerakan Literasi Sekolah sebagai Sumber Belajar terhadap Peningkatan Pengetahuan Kewarganegaraan (Civic Knowledge) Peserta Didik (Studi Korelasional di Sekolah Menengah Atas Negeri 4 Bandung). Universitas Pendidikan Indonesia.

Putri, R. S., Purwanto, A., Pramono, R., Asbari, M., Wijayanti, L. M., \& Hyun, C. C. (2020). Impact of the COVID-19 pandemic on online home learning: An explorative study of primary schools in Indonesia. International Journal of Advanced Science and Technology, 29(5), 4809-4818.

Reimers, F., Schleicher, A., Saavedra, J., \& Tuominen, S. (2020). Supporting the continuation of teaching and learning during the COVID-19 pandemic. Annotated resources for online learning. In OECD Publishing.

Richey, R. C., \& Klein, J. D. (2014). Design and Development Research. In Handbook of Research on Educational Communications and Technology: Fourth Edition (pp. 1-1005). https://doi.org/10.1007/978-1-4614-3185-5

Rusiadi, R., Aprilia, A., Adianti, V., \& Verawati, V. (2020). Dampak Covid-19 Terhadap Stabilitas Ekonomi Dunia (Studi 14 Negara Berdampak Paling Parah). Jepa, 5(2), 173-182.Saiful Mujani Research \& Consulting. (2020). Asesmen Publik Tentang Pendidikan Online di Masa COVID-19.

Schleicher, A. (2020). the Impact of Covid-19 on Education Insights From Education At a Glance 2020. 1-31.

Sudjana, N. (1989). Teknologi Pengajaran. Sinar Baru.

Suharti, A. (2020). Layanan Perpustakaan Di Masa Pandemi. Buletin Perpustakaan Universitas Islam Indonesia, 3(2), 53-63.

Sumiati, \& Asra. (2008). Metode Pembelajaran. Wacana Prima.

Syukur, F. (2008). Teknologi Pendidikan. Rasial Media Group.

Telaumbanua, D. (2020). Urgensi Pembentukan Aturan Terkait Pencegahan Covid-19 di Indonesia. QALAMUNA: Jurnal Pendidikan, Sosial, Dan Agama, 12(01), 59-70. https://doi.org/10.37680/qalamuna.v12i01.290

The Center for Disease Control and Prevention. (2020). Symptoms of Coronavirus |CDC.

Wahyono, P., Husamah, H., \& Budi, A. S. (2020). Guru profesional di masa pandemi COVID-19: Review implementasi, tantangan, dan solusi pembelajaran daring. Jurnal Pendidikan Profesi Guru, 1(1), 51-65.

Winata, A. P., Fadelina, R., \& Basuki, S. (2021). New normal and library services in Indonesia: a case study of university libraries. Digital Library Perspectives, 37(1), 77-84. https://doi.org/10.1108/DLP-07-2020-0059 
World Health Organisation. (2020). Coronavirus disease (COVID-19).

Yang, X., Yu, Y., Xu, J., Shu, H., Xia, J., Liu, H., Wu, Y., Zhang, L., Yu, Z., Fang, M., Yu, T., Wang, Y., Pan, S., Zou, X., Yuan, S., \& Shang, Y. (2020). Clinical course and outcomes of critically ill patients with SARS-CoV-2 pneumonia in Wuhan, China: a single-centered, retrospective, observational study. The Lancet Respiratory Medicine, 8(5), 475-481. https://doi.org/10.1016/S2213-2600(20)30079-5

Yuliani, T., \& Nugraha, H. (2021). Pemanfaatan Aplikasi WhatsApp sebagai Sirkulasi Sumber Belajar di Perpustakaan Tasyaa. Jurnal Inovasi Kurikulum, 1, 54-62. 